\title{
A survey on composition and microbiota of fresh and fermented yak milk at different Tibetan altitudes
}

\author{
Xiao-He $\mathrm{Wu}^{1 * *}$, Zhang Luo ${ }^{2 * *}$, $\mathrm{Li} \mathrm{Yu}^{1}$, Fa-Zheng ReN ${ }^{1}$, Bei-Zhong HaN ${ }^{1 *}$, \\ M.J. Robert NouT ${ }^{3}$ \\ ${ }^{1}$ College of Food Science and Nutritional Engineering, China Agricultural University, \\ Beijing 100083, P. R. China \\ ${ }^{2}$ College of Agriculture and Animal Husbandry, Tibet University, Linzhi 860000, P. R. China \\ ${ }^{3}$ Laboratory of Food Microbiology, Wageningen University, Wageningen EV 6700, The Netherlands
}

Received 28 August 2008 - Accepted 20 January 2009

\begin{abstract}
Yak milk is a type of milk that people are less familiar with due to its remote geographical location, the particular geographical environment and climatic conditions in Tibet, which may have significant effects on composition, microbiota and fermentation outcome. To investigate the chemical composition and microbiota of fresh and fermented yak milk, and to isolate and characterize the predominant microorganisms in the fermented milk, yak milk ( 24 fresh and 30 fermented milk samples) was collected from four areas of different altitudes in Tibet, and their microbiological profile and chemical composition were investigated. Yak milk had a higher fat, crude protein, lactose and dry matter content than cow milk. The fermented yak milk showed a great diversity in fat and dry matter levels due to the different ways of processing in different localities, and lower $\mathrm{pH}$ and higher lactic acid content compared with commercial cow milk yogurt. Fermented yak milk had a better sanitary quality than fresh yak milk. Three species of lactobacilli (Lactobacillus fermentum, Lactobacillus helveticus and Lactobacillus curvatus) and five species of yeast (Saccharomyces cerevisiae, Candida kefyr, Candida lambica, Candida famata and Candida holmii) were identified phenotypically and encountered as predominant fermentation microbiota. The predominant lactic species in fermented milk was L. fermentum.
\end{abstract}

yak milk / composition / microbiota / fermented milk

摘要 - 西藏不同海拔地区牦牛鲜乳和发酵乳理化指标和微生物组成的研究。牦牛乳是一种 独特却少为人知的乳品。西藏地理和气候条件特殊, 其牦牛乳成分、微生物组成和发酵乳 产品极为特殊。为了调查牦牛鲜乳和发酵乳的理化、微生物组成, 并从发酵乳中分离和鉴 定优势菌株, 本文对来自西藏 4 个不同海拔地区的牦牛乳样品 $(24$ 个鲜乳和 30 个发酵乳样 品) 进行了理化和微生物学分析。与牛乳相比, 牦牛鲜乳含有较高的脂肪、粗蛋白、乳糖和 干物质。与普通酸奶相比较, 发酵牦牛乳则具有较低的 $\mathrm{pH}$ 值和较高的乳酸含量, 而由于各 地人工操作工艺的差别致使发酵牦牛乳脂肪和干物质的含量具有显著的波动性。微生物 学分析表明发酵牛牛乳比牦牛鲜乳更卫生。发酵牛牛乳中的优势菌群由计数法得以确定, 并由 表型特征鉴定为 3 种乳酸杆菌: Lactobacillus fermentum、Lactobacillus helveticus 和 Lactobacillus

*Corresponding author (通讯作者): bz.han@cau.edu.cn

**Both authors contributed equally to this paper. 
curvatus, 以及 5 种酵母菌: Saccharomyces cerevisiae、Candida kefyr、Candida lambica、Candida famata 和 Candida holmii, 其中 L. fermentum 是主要的产乳酸菌种。

\title{
牦牛乳 / 组成 / 微生物菌相 / 发醳乳
}

\begin{abstract}
Résumé - Composition et flore microbienne de lait de yak frais et fermenté du Tibet à différentes altitudes. Le lait de yak est un produit laitier particulier que peu de gens connaissent en raison de sa localisation géographique éloignée, de son environnement géographique particulier et des conditions climatiques du Tibet qui peuvent avoir des effets significatifs sur sa composition, sa flore microbienne et sa fermentation ultérieure. Pour étudier la composition chimique et la flore microbienne de lait de yak frais et fermenté, et pour isoler et caractériser les microorganismes prédominants dans les laits fermentés, du lait de yak (24 échantillons de lait frais et 30 de lait fermenté) a été collecté à différentes altitudes au Tibet. Le lait de yak avait des teneurs en matière grasse, protéines totales, lactose et matière sèche plus élevées que le lait de vache. Le lait de yak fermenté présentait une grande diversité des taux de matière grasse et matière sèche en raison des différents modes de traitement dans les différentes localités, et un $\mathrm{pH}$ plus faible et une teneur plus élevée en acide lactique que le yaourt commercial au lait de vache. Le lait de yak fermenté avait une meilleure qualité sanitaire que le lait de yak frais. Trois espèces de lactobacilles (Lactobacillus fermentum, Lactobacillus helveticus et Lactobacillus curvatus) et cinq espèces de levures (Saccharomyces cerevisiae, Candida kefyr, Candida lambica, Candida famata et Candida holmii) ont été identifiées phénotypiquement et s'avéraient constituer la flore microbienne de fermentation prédominante. L'espèce lactique prédominante dans le lait fermenté était L. fermentum.
\end{abstract}

lait de yak / composition / flore microbienne / lait fermenté

\section{INTRODUCTION}

Traditional fermented milk products such as Dahi, Kefir and Koumiss [4] enjoy popularity with many consumers worldwide because of their shelf life and particular flavor produced by natural microbiota. Untill now, very little is known about the popular fermented yak milk of Tibet; this is not surprising considering the remote geographical location. Yak (Bos gruniens) is a specific type of cattle which is well-suited to the climatic conditions of the Qingzang plateau and its surrounding regions [14]. Compared with cow milk, yak milk has a higher content of fat, crude protein, lactose and dry matter, as well as more vitamin $\mathrm{B}$, free amino acids and a lower content of cholesterol $[8,13]$.

Traditional fermented yak milk products in Tibet are still made at the household level in earthenware, metal or wooden containers [22], following the traditional processing procedure: (1) boiling and cooling the milk, (2) skimming the lipids artificially, (3) inoculation using back-slopping as an enrichment-starter and (4) fermentation overnight at ambient temperature.

Fermented yak milk possesses a particular yak milk flavor, and is yeasty-sweet, which indicates that a complex microbiota, not only lactic acid bacteria (LAB), plays a significant role in the fermentation process $[1,7]$. Environmental factors, such as temperature, oxygen concentration and moisture can influence the activities of microorganisms. The particular geographical environment and climatic conditions in Tibet may have more pronounced effects on microbiota composition and fermentation outcome. New isolates of LAB and yeast may be of interest to the dairy industry for the development of starter cultures and novel products.

The objectives of this study were to investigate the composition and microbiota 
of fresh and fermented yak milk, and to isolate and characterize the predominant LAB and yeast species in the fermented milk.

\section{MATERIALS AND METHODS}

\subsection{Sampling}

Fermented yak milk: 30 samples were collected from four different areas within $24 \mathrm{~h}$ after milking, comprising eight samples from Lulang district $(3300 \pm 50 \mathrm{~m}$, average temperature $\left.12.6{ }^{\circ} \mathrm{C}\right), 12$ samples from Songduo district $(4300 \pm 50 \mathrm{~m}$, average temperature $10{ }^{\circ} \mathrm{C}$ ), four samples from Anduo district $(5000 \pm 50 \mathrm{~m}$, average temperature $7.6^{\circ} \mathrm{C}$ ) and six samples from Milashan district $(5020 \pm 50 \mathrm{~m}$, average temperature $6.8{ }^{\circ} \mathrm{C}$ ). All the samplings were carried out in July, in the summer.

Fresh yak milk: 24 samples were obtained from Lulang, Songduo and Milashan districts during July, which is the major lactation period of yaks. Milking was carried out manually in the morning, and eight samples from each altitude were taken.

About $500 \mathrm{~mL}$ of milk was obtained for chemical and microbiological analyses. All samples were kept on ice for $\sim 4$ h of transport and were analyzed immediately after arrival at the laboratory.

\subsection{Chemical analysis}

Contents of fat and crude protein were determined by the Gerber method [10] and Kjeldahl method [2], respectively. Lactose was determined by colorimetric method according to the Chinese standard method [18]. Briefly, after sediment of protein by zinc sulfate and caustic baryta, lactose in the supernatant was reacted with the addition of phenol, sodium hydroxyl, trinitrophenol and sodium bisulfite, and then determined with spectrophotometer by standard curve method. Total dry matter and ash were obtained after drying to constant weight by conventional oven-drying $\left(60{ }^{\circ} \mathrm{C}\right.$ for $2-3 \mathrm{~h}$, then $100{ }^{\circ} \mathrm{C}$ for $\left.4 \mathrm{~h}\right)$ and muffle furnace $\left(550{ }^{\circ} \mathrm{C}\right.$ for $\left.3 \mathrm{~h}\right)$ of $5 \mathrm{~g}$ milk sample. Titratable acidity was measured with titrimetric analysis [9] and $\mathrm{pH}$ was determined by direct measurement with a HANNA pH 211 meter (Italy). Triplicate tests were performed for each analysis.

\subsection{Microbiological analysis}

Serial dilutions of fresh and fermented yak milk were made in $0.85 \% \mathrm{NaCl}$ solution and pour-plated in triplicate on different media. The total counts of mesophilic aerobic bacteria (TCs) were enumerated using $3 \mathrm{M}$ Petrifilm ${ }^{\mathrm{TM}}$ Aerobic Count Plate (3M, USA) after incubation at $35^{\circ} \mathrm{C}$ for 2 days. LAB were enumerated in pour plates of de Man, Rogosa and Sharpe Medium (MRS, Merck, Germany) after incubation at $37^{\circ} \mathrm{C}$ aerobically for 3 days. Yeasts were enumerated using potato dextrose agar (PDA, Luqiao, China) after incubation at $25{ }^{\circ} \mathrm{C}$ for 5 days. Coliforms were enumerated using 3M Petrifilm ${ }^{\mathrm{TM}}$ Escherichia coli/ Coliform Plate (3M, USA), after incubation at $37^{\circ} \mathrm{C}$ for 1 day, and $E$. coli for 2 days. Staphylococcus aureus were enumerated using 3M Petrifilm ${ }^{\mathrm{TM}}$ Staph Express Count Plate and Disk (3M, USA) after incubation at $37{ }^{\circ} \mathrm{C}$ for 1 day. To detect bacterial endospores (BS), milk samples were first pasteurized $\left(80^{\circ} \mathrm{C}, 10 \mathrm{~min}\right)$ and then surviving mesophilic bacteria were enumerated using 3M Petrifilm ${ }^{\mathrm{TM}}$ Aerobic Count Plate, after incubation at $35^{\circ} \mathrm{C}$ for 2 days.

\subsection{Identification of $L A B$ and yeasts}

Typical LAB on MRS were confirmed initially for their Gram stain, oxidase and catalase tests. Only gram-positive bacteria with oxidase and catalase negative reactions were observed and purified by successive streaking onto MRS. Typical yeast colonies 
on PDA were examined by microscopy, purified by successive streaking on PDA. All isolated microorganisms were recorded and stored at $4{ }^{\circ} \mathrm{C}$ for further identification.

After the preliminary confirmation of $\mathrm{LAB}$ and yeasts, selected strains were further identified on phenotype using assimilation and fermentation kits API $50 \mathrm{CH}$ (BioMérieux, Marcy-l'Étoile, France) for $\mathrm{LAB}$ and ID $32 \mathrm{C}$ (BioMérieux, Marcy-l'Étoile, France) for yeasts, respectively. The data were analyzed using ATB Plus software (BioMérieux).

\subsection{Statistical analysis}

All microbial counts were converted to the base-10 logarithm of the number of colony forming units per millilitre of fermented milk samples (log cfu $\left.\mathrm{mL}^{-1}\right)$. When studying the effects of altitude on the composition of physicochemical and microbiological distribution, we considered Anduo district and Milashan district to be of the same altitude $(5010 \pm 50 \mathrm{~m})$. The chemical and microbiological composition of yak milk was evaluated with analysis of variance through the Ryan-Einot-Gabriel-Welsch multiple range test of the Statistical Analysis System software (SAS version 9.0, SAS Institute Inc., 2002). Least significant differences were used to separate means at $P<0.05$.

\section{RESULTS AND DISCUSSION}

\subsection{Chemical composition}

The chemical composition of fresh and fermented yak milk is given in Table I. Fresh milk contained higher level of fat, lactose and dry matter compared to fermented milk. Although the acidity of fermented milk was higher than that of fresh milk, as given in Table I, with lower $\mathrm{pH}$ and higher titratable acidity, levels of crude protein and ash were similar in both types of milk.

At higher altitudes, we noticed a significant $(P<0.05)$ increase in fat and dry matter content of fresh milk, as given in Table I. In fermented yak milk, we observed considerable variability of fat and dry matter levels, ranging from $0.92 \%$ and $11.26 \%$ to $7.30 \%$ and $17.95 \%$, respectively. The differences in the composition of fermented milk might attribute to the altitude, pre-processing or fermentation processing, because the local habitants still adopted the diverse empiric methods to make fermented yak milk, for example skimming method, natural starters or fermentation method. The average lactose content reached $2.26 \%$, which was about half of the lactose level in fresh milk, whereas the average protein content was $4.91 \%$, slightly lower than that in fresh yak milk.

The average $\mathrm{pH}$ value of fermented yak milk was 3.92, which was similar to the data reported by Abdelgadir et al. [1], while being lower than those of Mathara et al. [16]. Interesting to note is that the very high level of titratable acidity expressed by lactic acid content, reached $1.93 \pm 0.17 \%(\mathrm{w} / \mathrm{w})$, which was considerably higher than the commercial cow milk yoghurt and Kefir, and more comparable to the Koumiss of Russia [4].

\subsection{Microbiota}

Table II summarizes the microbiological composition of fresh and fermented yak milk. In general, fresh yak milk was of poor sanitary quality as evidenced by relatively high numbers of coliforms, E. coli and $S$. aureus. The fresh yak milk obtained from the highest altitude had significantly higher levels of LAB, yeasts and E. coli compared to those obtained from lower altitudes.

Fermented yak milk had much higher levels of $\mathrm{LAB}$ and yeasts than fresh yak milk and these were the predominating 
Table I. Chemical analysis of fresh and fermented yak milk obtained at different altitudes.

\begin{tabular}{|c|c|c|c|c|c|c|c|c|}
\hline \multirow[t]{2}{*}{ Altitude (m) } & \multicolumn{4}{|c|}{ Fresh yak milk } & \multicolumn{4}{|c|}{ Fermented yak milk } \\
\hline & $\begin{array}{c}3300 \pm 50 \\
(n=8)\end{array}$ & $\begin{array}{c}4300 \pm 50 \\
(n=8)\end{array}$ & $\begin{array}{c}5010 \pm 50 \\
\quad(n=8)\end{array}$ & $\begin{array}{l}\text { Average } \\
(n=24)\end{array}$ & $\begin{array}{c}3300 \pm 50 \\
(n=8)\end{array}$ & $\begin{array}{c}4300 \pm 50 \\
(n=12)\end{array}$ & $\begin{array}{c}5010 \pm 50 \\
(n=10)\end{array}$ & $\begin{array}{l}\text { Average } \\
(n=30)\end{array}$ \\
\hline Fat $(\%, v / v)$ & $6.98 \pm 0.28^{\mathrm{a}, *}$ & $7.14 \pm 0.26^{\mathrm{ab}}$ & $7.34 \pm 0.26^{\mathrm{b}}$ & $7.15 \pm 0.30$ & $2.52 \pm 1.75^{\mathrm{a}}$ & $6.39 \pm 1.12^{\mathrm{b}}$ & $5.77 \pm 1.75^{\mathrm{b}}$ & $5.15 \pm 2.18$ \\
\hline Crude protein $(\%, \mathrm{w} / \mathrm{w})$ & $4.99 \pm 0.17^{\mathrm{a}}$ & $4.98 \pm 0.36^{\mathrm{a}}$ & $5.16 \pm 0.22^{\mathrm{a}}$ & $5.04 \pm 0.27$ & $4.89 \pm 0.16^{\mathrm{a}}$ & $4.89 \pm 0.08^{\mathrm{a}}$ & $4.96 \pm 0.41^{\mathrm{a}}$ & $4.91 \pm 0.24$ \\
\hline Lactose $(\%, w / w)$ & $4.92 \pm 0.30^{\mathrm{a}}$ & $4.97 \pm 0.26^{\mathrm{a}}$ & $5.01 \pm 0.19^{\mathrm{a}}$ & $4.99 \pm 0.26$ & $2.30 \pm 0.04^{\mathrm{a}}$ & $2.25 \pm 0.01^{\mathrm{a}}$ & $2.25 \pm 0.01^{\mathrm{a}}$ & $2.26 \pm 0.03$ \\
\hline Dry matter $(\%, w / w)$ & $18.18 \pm 0.52^{\mathrm{a}}$ & $18.17 \pm 0.31^{\mathrm{a}}$ & $18.78 \pm 0.54^{\mathrm{b}}$ & $18.38 \pm 0.53$ & $12.91 \pm 1.37^{\mathrm{a}}$ & $15.59 \pm 0.80^{\mathrm{b}}$ & $15.84 \pm 1.59^{\mathrm{b}}$ & $14.96 \pm 1.73$ \\
\hline Ash $(\%, w / w)$ & $0.80 \pm 0.04^{\mathrm{a}}$ & $0.81 \pm 0.02^{\mathrm{a}}$ & $0.82 \pm 0.03^{\mathrm{a}}$ & $0.81 \pm 0.02$ & $0.84 \pm 0.01^{\mathrm{a}}$ & $0.88 \pm 0.08^{\mathrm{a}}$ & $0.91 \pm 0.04^{\mathrm{a}}$ & $0.88 \pm 0.06$ \\
\hline $\mathrm{pH}$ & $6.47 \pm 0.04^{\mathrm{a}}$ & $6.48 \pm 0.07^{\mathrm{a}}$ & $6.51 \pm 0.03^{\mathrm{a}}$ & $6.48 \pm 0.05$ & $3.91 \pm 0.09^{\mathrm{a}}$ & $3.88 \pm 0.15^{\mathrm{a}}$ & $4.00 \pm 0.06^{\mathrm{a}}$ & $3.92 \pm 0.12$ \\
\hline Lactic acid $(\%, w / w)$ & $0.17 \pm 6.53^{\mathrm{a}}$ & $0.16 \pm 0.01^{\mathrm{a}}$ & $0.17 \pm 0.06^{\mathrm{a}}$ & $0.17 \pm 0.01$ & $2.05 \pm 0.06^{\mathrm{a}}$ & $1.97 \pm 0.18^{\mathrm{a}}$ & $1.78 \pm 0.12^{\mathrm{a}}$ & $1.93 \pm 0.17$ \\
\hline
\end{tabular}

$n$ : number of samples.

* Mean \pm SD

${ }^{\text {abc }}$ Mean values bearing different superscripts in the same row differ significantly $(P<0.05)$. 
Table II. Microbiota of fresh and fermented yak milk at different altitudes $\left(\log \mathrm{cfu} \cdot \mathrm{mL}^{-1}\right)$.

\begin{tabular}{|c|c|c|c|c|c|c|c|c|}
\hline \multirow[t]{2}{*}{ Altitude (m) } & \multicolumn{4}{|c|}{ Fresh yak milk } & \multicolumn{4}{|c|}{ Fermented yak milk } \\
\hline & $\begin{array}{c}3300 \pm 50 \\
(n=8)\end{array}$ & $\begin{array}{c}4300 \pm 50 \\
(n=8)\end{array}$ & $\begin{array}{c}5010 \pm 50 \\
(n=8)\end{array}$ & $\begin{array}{l}\text { Average } \\
(n=24)\end{array}$ & $\begin{array}{c}3300 \pm 50 \\
(n=8)\end{array}$ & $\begin{array}{c}4300 \pm 50 \\
(n=10)\end{array}$ & $\begin{array}{c}5010 \pm 50 \\
(n=24)\end{array}$ & $\begin{array}{l}\text { Average } \\
(n=30)\end{array}$ \\
\hline $\mathrm{TC}$ & $5.66 \pm 0.52^{\mathrm{a}, *}$ & $6.01 \pm 0.40^{\mathrm{a}}$ & $5.15 \pm 0.89^{b}$ & $5.58 \pm 0.74$ & $7.60 \pm 0.27^{\mathrm{a}}$ & $7.90 \pm 0.39^{\mathrm{a}}$ & $8.23 \pm 0.24^{b}$ & $7.93 \pm 0.39$ \\
\hline BS & $2.51 \pm 0.42^{\mathrm{a}}$ & $1.80 \pm 0.78^{b}$ & $1.47 \pm 0.36^{\mathrm{c}}$ & $1.93 \pm 0.69$ & $2.73 \pm 1.82^{\mathrm{a}}$ & $3.78 \pm 0.68^{\mathrm{b}}$ & $3.92 \pm 0.47^{b}$ & $3.55 \pm 1.10$ \\
\hline LAB & $4.86 \pm 0.39^{\mathrm{a}}$ & $5.25 \pm 0.54^{\mathrm{a}}$ & $5.80 \pm 0.16^{\mathrm{b}}$ & $5.69 \pm 0.43$ & $8.17 \pm 1.32^{\mathrm{a}}$ & $8.36 \pm 0.65^{\mathrm{a}}$ & $7.95 \pm 0.28^{\mathrm{a}}$ & $8.17 \pm 0.76$ \\
\hline Yeasts & $2.28 \pm 0.43^{\mathrm{a}}$ & $2.65 \pm 0.24^{\mathrm{a}}$ & $3.40 \pm 0.46^{\mathrm{b}}$ & $3.28 \pm 1.02$ & $7.47 \pm 0.47^{\mathrm{a}}$ & $7.40 \pm 0.99^{\mathrm{a}}$ & $7.19 \pm 0.8^{\mathrm{a}}$ & $7.35 \pm 0.78$ \\
\hline Coliforms & $3.62 \pm 0.34^{\mathrm{a}}$ & $3.20 \pm 0.34^{\mathrm{b}}$ & $3.23 \pm 0.26^{\mathrm{b}}$ & $3.47 \pm 0.37$ & $<1$ & $<1$ & $<1$ & $<1$ \\
\hline E. coli & $1.03 \pm 0.51^{\mathrm{a}}$ & $1.63 \pm 0.62^{\mathrm{b}}$ & $3.00 \pm 0.37^{\mathrm{c}}$ & $2.01 \pm 1.09$ & $<1$ & $<1$ & $<1$ & $<1$ \\
\hline S. aureus & $3.53 \pm 0.58^{\mathrm{a}}$ & $3.27 \pm 0.33^{\mathrm{a}}$ & $3.67 \pm 0.62^{\mathrm{a}}$ & $3.51 \pm 0.64$ & $<1$ & $<1$ & $<1$ & $<1$ \\
\hline
\end{tabular}

TC: total count of mesophilic aerobic bacteria; BS: bacterial endospores; LAB: lactic acid bacteria; $n$ : number of samples.

* Mean \pm SD.

${ }^{a b c}$ Mean values bearing different superscripts in the same row differ significantly $(P<0.05)$. 
Table III. Identification and distribution of LAB and yeasts in fermented yak milk of different altitudes in Tibet.

\begin{tabular}{lccc}
\hline Identified species & \multicolumn{3}{c}{ Percentage of $n\left(\mathrm{cfu} \cdot \mathrm{mL}^{-1}\right)$ based on identified isolates } \\
\cline { 2 - 4 } & $3300 \pm 50(\mathrm{~m})$ & $4300 \pm 50(\mathrm{~m})$ & $5010 \pm 50(\mathrm{~m})$ \\
\hline L. curvatus & $\mathrm{ND}$ & 3.9 & $\mathrm{ND}$ \\
L. fermentum & 83.0 & 84.3 & 85.2 \\
L. helveticus & 0.3 & 2.0 & $\mathrm{ND}$ \\
C. holmii & $\mathrm{ND}$ & $\mathrm{ND}$ & 1.9 \\
C. kefyr & 13.5 & 5.0 & 0.1 \\
C. lambica & 0.4 & 0.5 & 1.7 \\
S. cerevisiae & 2.8 & 4.3 & 11.4 \\
\hline
\end{tabular}

ND: not detected.

microorganisms. Table II showed that the ratio of $\mathrm{LAB} /$ yeasts fluctuates around 85/ 15 at all altitudes and there was no significant shift in this ratio caused by altitude. The concentration of BS was considerably higher in fermented milk than that in fresh milk. This might be caused by the growth of contamination sporulating bacteria during fermentation. In comparison with fresh yak milk, it was remarkable that in all fermented yak milks, the levels of coliforms, E. coli and $S$. aureus remained below the detectable level. Obviously, this was the result of the significant acidity with high level of titratable acid.

Fermented yak milk had level of LAB that fulfilled the requirement of Chinese standard [19] which specified that LAB shall be above $6 \log \mathrm{cfu} \cdot \mathrm{mL}^{-1}$. In addition, the second predominating groups of microorganisms were yeasts (ranging from 5.52 to $8.25 \log \mathrm{cfu} \cdot \mathrm{mL}^{-1}$, averaging $7.35 \log \mathrm{cfu} \cdot \mathrm{mL}^{-1}$ ). Yeasts were commonly encountered in naturally fermented milks $[3,5,7,16]$, and originate from the environment and utensils, especially the fermentation vessel. According to Fleet and Mian [6], yeast level of $10^{5-6} \mathrm{cfu} \cdot \mathrm{mL}^{-1}$ in dairy products was associated with spoilage. However, according to our study, the yeasts might be considered as an important component of the microbiota of Tibetan fermented yak milk due to their broad exist and stable ratio versus $\mathrm{LAB}$ in this local dairy product. According to Mathara et al. [16], $\mathrm{pH}$ values of milk fermented by mixed $\mathrm{LAB}$ and yeasts were usually $<4.5$, and this is confirmed by our analysis.

\subsection{Isolation and identification of LAB and yeasts}

From 30 fermented yak milk samples, 62 isolates of $\mathrm{LAB}$ and 52 isolates of yeasts were identified phenotypically (Tab. III). The LAB, such as Lactobacillus fermentum, Lactobacillus helveticus and Lactobacillus curvatus, and yeasts, such as Saccharomyces cerevisiae, Candida kefyr, Candida lambica, Candida famata and Candida holmii were finally isolated and identified from fermented yak milk.

Lactobacillus fermentum, L. helveticus and L. curvatus were isolated from milk products by Miyamoto et al. [17]. S. cerevisiae and C. kefyr were isolated in several studies of raw and fermented milks $[6,11$, 15]. S. cerevisiae would grow in milk without the addition of lactose or galactose [20]. Tempel and Jakobsen [21] reported there was $S$. cerevisiae in raw milk but in low numbers. The positive contribution by yeasts to aroma formation and probiotic 
properties was reviewed by Jakobsen and Narvhus [12].

According to the data in Table III, of the LAB, L. fermentum was predominant at all altitudes that were investigated. Among the yeasts, predominance showed a significant shift from C. kefyr at $3300 \mathrm{~m}$ to $S$. cerevisiae at $5010 \mathrm{~m}$. The reason for shifting is still unknown. However, it might indicate that the presence of yeast played an important role in the fermentation of yak milk.

\section{CONCLUSION}

Yak milk and fermented yak milk are specific dairy products which are wellsuited to the climatic conditions of the Qingzang plateau and the surrounding regions. Environmental and processing factors, such as altitude, temperature, oxygen concentration, moisture and practical processing, can influence their composition and microbiota more or less.

Fermented yak milk has a better sanitary quality than fresh yak milk. The presence of $L$. fermentum with $C$. kefyr and $S$. cerevisiae as predominant microorganisms appears to be stable and opens up opportunities for the development of mixed culture starters for the dairy industry. New isolates of $\mathrm{LAB}$ and yeasts may be of interest to the dairy industry for the development of starter cultures and novel products.

Acknowledgements: This work was supported by the National Key Project of Scientific and Technical Supporting Programs Funded by the Ministry of Science and Technology of China (2006BAD04A06).

\section{REFERENCES}

[1] Abdelgadir W.S., Hamad S.H., Møller P.L., Jakobsen M., Characterisation of the domi- nant microbiota of Sudanese fermented milk, Int. Dairy J. 11 (2001) 63-70.

[2] AOAC, Association of Official Analytical Chemists, Official Methods of Analysis, 16th edn., Arlington, VA, USA, 1995.

[3] Beukes E.M., Bester B.H., Mostert J.F., The microbiology of South African traditional fermented milks, Int. J. Food Microbiol. 63 (2001) 189-197.

[4] Chandan R.C., White C.H., Kilara A., Hui Y.H., Manufacturing Yogurt and Fermented Milks, Blackwell Publishing Ltd., Iowa, USA, 2006.

[5] Fleet G.H., Yeasts in dairy products - a review, J. Appl. Bacteriol. 68 (1990) 199-211.

[6] Fleet G.H., Mian M.A., The occurrence and growth of yeasts in dairy products, Int. J. Food Microbiol. 4 (1987) 145-155.

[7] Gadaga T.H., Mutukumira A.N., Narvhus J.A., The growth and interaction of yeasts and lactic acid bacteria isolated from Zimbabwean naturally fermented milk in UHT milk, Int. J. Food Microbiol. 68 (2001) 21-32.

[8] Huang Y.S., Development of yak food industry, China Dairy Ind. 28 (2000) 14-16 [in Chinese].

[9] IDF, International Dairy Federation, Yoghurt. Determination of titrable acidity (potentiometric method), 1991 [IDF 150].

[10] ISO, International Organization for Standardization, Milk determination of fat content (routine method), 1976 [ISO 2446].

[11] Iwasawa S., Ueda M., Miyata N., Hirota T., Ahiko K., Identification and fermentation character of Kefir yeast, Agric. Biol. Chem. 46 (1982) 2631-2636.

[12] Jakobsen M., Narvhus J., Yeasts and their possible beneficial and negative effects on the quality of dairy products, Int. Dairy J. 6 (1996) 755-768.

[13] Liu H.B., Pen Z.K., Lei H.Z., Chen Y.N., Liu S.Q., Li K.L., Zhang J.W., Liu Z.B., Ma Z.X., Liu G.L., Li Y.S., China Yak, Szechwan Science and Technology Press, Chengdu, China, 1987 [in Chinese].

[14] Ma S.W., Yang X.X., Developing and outlook of yak dairy products, Food Res. Dev. 22 (Suppl.) (2001) 44-45 [in Chinese].

[15] Marshall V.M.E., The microflora and production of fermented milks, Prog. Ind. Microbiol. 23 (1986) 1-44.

[16] Mathara J.M., Schillinger U., Kutima P.M., Isolation, identification and characterization of the dominant microorganisms of kule 
naoto: the Maasai traditional fermented milk in Kenya, Int. J. Food Microbiol. 94 (2004) 269-278.

[17] Miyamoto T., Gichuru S.G.G., Akimoto T., Nakae T., Identification and properties of lactic acid bacteria isolated from traditional fermented beverages in East Africa, Jpn. J. Zootech. Sci. 57 (1989) 256-276 [in Japanese].

[18] MOA, Ministry of Agriculture of the People's Republic of China, Determination of lactose in milk and milk products (enzyme-colorimetric method), 2007 [NY/T 1422-2007].
[19] MOH, Ministry of Health of the People's Republic of China, Hygienic standard for Lactobacillus beverage, 2003 [GB 163212003].

[20] Neviani E., Gatti M., Vannini L., Gardini F., Suzzi G., Contribution of Gal - lactic acid bacteria to Saccharomyces cerevisiae metabolic activity in milk, Int. J. Food Microbiol. 69 (2001) 91-99.

[21] Tempel T., Jakobsen M., Yeasts associated with Danablu, Int. Dairy J. 8 (1998) 25-31.

[22] Yan P., Pan H.P., Development and utilization of yak milk industry, China Dairy 7 (2004) 10-12 [in Chinese]. 